\title{
Influx of Thyroid Hormones into Rat Liver In Vivo
}

\author{
DIFFERENTIAL AVAILABILITY OF THYROXINE AND TRIIODOTHYRONINE \\ BOUND BY PLASMA PROTEINS
}

\begin{abstract}
William M. Pardridge and Lawrence J. Mietus, Department of Medicine, Division of Endocrinology and Metabolism, University of California at Los Angeles School of Medicine, Los Angeles, California 90024
\end{abstract}

\begin{abstract}
A B S T R A C T The transport of [ $\left.{ }^{125} \mathrm{I}\right]$ thyroxine $\left(\mathrm{T}_{4}\right)$ and $\left[{ }^{125} \mathrm{I}\right]$ triiodothyronine $\left(\mathrm{T}_{3}\right)$ into liver was investigated with a tissue sampling-portal vein injection technique in the anesthetized rat. The method allows the investigation of the effects of plasma proteins in human serum on the unidirectional influx of $\mathrm{T}_{4}$ or $\mathrm{T}_{3}$ into liver cells. The percent extraction of unidirectional clearance of $\mathrm{T}_{3}$ and $\mathrm{T}_{4}$ was $77 \pm 2 \%$ and $43 \pm 2 \%$, respectively, after portal injection of a bolus of Ringer's solution. Cell membrane transport of $\mathrm{T}_{4}$ or $\mathrm{T}_{3}$ was nonsaturable because $50-\mu \mathrm{M}$ concentrations of unlabeled hormone had no effect on transport. The addition of bovine albumin in concentrations of 1,5 , or $10 \mathrm{~g} / 100$ $\mathrm{ml}$ bound $>98 \%$ of $\mathrm{T}_{4}$ or $\mathrm{T}_{3}$ in vitro, but had no significant effect on $\mathrm{T}_{3}$ or $\mathrm{T}_{4}$ transport in vivo. Conversely, $10 \%$ rabbit antisera specific for $\mathrm{T}_{3}$ or $\mathrm{T}_{4}$, completely abolished the intracellular distribution of thyroid hormone into liver. In the presence of rat serum, which contains albumin and thyroid hormone binding prealbumin (TBPA), 18 and $81 \%$ of total plasma $\mathrm{T}_{4}$ and $\mathrm{T}_{3}$, respectively, were available for transport in vivo. The fraction of hormone available for transport in the presence of normal human serum, which contains albumin, TBPA, and thyroid hormone binding globulin (TBG) was $11 \%$ for $\mathrm{T}_{4}$ and $72 \%$ for $\mathrm{T}_{3}$. The fraction of hormone transported into liver after injection of serum obtained from pregnant or birth control pilltreated volunteers was $4 \%$ for $\mathrm{T}_{4}$ (but this was not significantly different from zero) and $54 \%$ for $\mathrm{T}_{3}$.
\end{abstract}

These data suggest: $(a)$ The mechanism by which $\mathrm{T}_{4}$ and $T_{3}$ traverse the liver cell membrane is probably free diffusion. (b) Albumin-bound $\mathrm{T}_{4}$ or $\mathrm{T}_{3}$ is freely cleared by liver, $\sim 50 \%$ of TBG-bound $\mathrm{T}_{3}$ is transported, but little, if any, of TBPA-bound $\mathrm{T}_{4}$ or TBG-bound $\mathrm{T}_{4}$ is

Dr. Pardridge was the recipient of Clinical Investigator Award AM-00409. Address reprint requests to Dr. Pardridge. Received for publication 5 November 1979 and in revised form 22 February 1980. cleared by liver cells. (c) Although the albumin-bound fraction of $\mathrm{T}_{4}$ greatly exceeds the free (dialyzable) moiety, the two fractions are both inversely related to the existing TBA or TBG level; therefore, in vitro measurements of free $T_{4}$ would be expected to accurately reflect what is available for transport in vivo. Conversely, TBG-bound $T_{3}$ is readily transported in vivo; therefore, it is proposed that in vitro measurements of free $T_{3}$ do not reliably predict the fraction of $T_{3}$ available for transport into liver in vivo.

\section{INTRODUCTION}

The thyroid and steroid hormones are tightly bound by plasma proteins (1), and it is generally regarded that only the small fraction that is free at equilibrium in vitro is available for transport in vivo (2). However, in vitro equilibrium measurements of ligand protein interactions do not bear on three important determinants of ligand transport in vivo: $(a)$ the rate of unidirectional ligand dissociation from the plasma protein, which is generally on the order of milliseconds to seconds, $(b)$ the capillary transit time $(1-10 \mathrm{~s})$, i.e., the duration of exposure of the plasma protein to the tissue cell membranes, and (c) membrane permeability, which determines the rate at which the ligand is transported through the biological membrane. Given favorable realtionships between these latter three determinants, the transport of protein-bound ligands may be extensive. Our previous studies with the steroid hormones have shown that albumin-bound, but not globulin-bound hormone is readily transported through the brain capillary wall, i.e., the blood-brain barrier (3); these results correlate with the fact that the rates of unidirectional dissociation of steroid from albumin and from globulin binding sites are fast and slow, respectively, relative to the capillary transit time in brain, $\sim 1$ s (3). Conversely, the rate of estradiol or cortisol dissociation from sex hormone binding globulin or 
corticosteroid binding globulin, respectively, is relatively fast $(4,5)$ compared with the long transit time in liver, 5-10 s (6). Moreover, both albumin-bound and globulin-bound estradiol or cortisol are available for transport into liver (7).

Based on studies reported by Hillier $(8,9)$ there is reason to believe that transport of protein-bound thyroid hormones into tissues is as extensive as observed for the steroid hormones. Hillier has shown that the $t_{1 / 2}$ at $37^{\circ} \mathrm{C}$ of triiodothyronine $\left(T_{3}\right)^{1}$ dissociation from thyroid hormone binding globulin (TBG) or albumin is $4 \mathrm{~s}$ and $<1 \mathrm{~s}$, respectively (8). The $t_{1 / 2}$ of unidirectional dissociation of thyroxine $\left(\mathrm{T}_{4}\right)$ from TBG or thyroid hormone binding prealbumin (TBPA) at $37^{\circ} \mathrm{C}$ is 39 and $8 \mathrm{~s}$, respectively (9); the $t_{1 / 2}$ of $T_{4}$ dissociation from albumin has apparently not been measured, but is probably on the same order of magnitude as $T_{3}$. It is assumed the data of Hillier $(8,9)$ provide at least estimates of the upper limit of thyronine debinding rates. Given these data and knowledge of the capillary transit times in tissues such as brain $(\sim 1 \mathrm{~s})$ or liver $(\sim 5 \mathrm{~s})$, it might be expected that $T_{3}$ bound to albumin, but not to TBG, is transported into brain. Indeed, recent studies have shown that the albumin-bound fraction of $\mathrm{T}_{3}$ transported into brain is 10 times the free (dialyzable) fraction (10). Moreover, it might be anticipated that $T_{3}$ bound to both albumin and to TBG is transported into a tissue such as liver with a long transit time of $\sim 5 \mathrm{~s}$. Similarly, a rapid unidirectional dissociation of $T_{4}$ from albumin might lead to transport of albumin-bound $T_{4}$ into liver, whereas $T_{4}$ bound to TBG and perhaps to TBPA may not dissociate within the hepatic capillary transit time. Therefore, the present studies were designed to investigate the hypothesis that the rates of unidirectional dissociation of thyroid hormones from plasma proteins reported by Hillier $(8,9)$ are predictive of which fraction (albumin, TBPA, TBG) of protein-bound hormone is transported into liver.

\section{METHODS}

All isotopes were purchased from New England Nuclear, Boston, Mass. The manufacturer specific activity was L- $\left[{ }^{125} \mathrm{I}\right]-$ thyroxine, $1,300 \mu \mathrm{Ci} / \mu \mathrm{g} ; \mathrm{L}-\left[{ }^{125} \mathrm{I}\right] 3,5,3^{\prime}$-triiodothyronine, 1,100 $\mu \mathrm{Ci} / \mu \mathrm{g}$; [ $\left.{ }^{125} \mathrm{I}\right]$ sodium iodide, $17,000 \mu \mathrm{Ci} / \mu \mathrm{g}$; and water- ${ }^{3} \mathrm{H}$, $1 \mathrm{mCi} / \mathrm{g}$. Bovine albumin (nondefatted), l-octanol and unlabeled $\mathrm{T}_{3}$ and $\mathrm{T}_{4}$ were purchased from Sigma Chemical Co., St. Louis, Mo. Serum was obtained from the rat, and the following human sources: normal male or female on no medications (ages 20-45 yr), females on birth control pills (Norinyl $1+50$ [Syntex Laboratories, Inc., Palo Alto, Calif.]; $1 \mathrm{mg}$ norethindrone and $50 \mu \mathrm{g}$ mestranol), third trimester pregnancy, and both male and female cord blood. Rabbit antisera specific for either $T_{3}$ or $T_{4}$ were obtained from Dr. Inder

${ }^{1}$ Abbreviations used in this paper: $\mathrm{E}_{\mathrm{T}}$, extraction of test compound; LUI, liver uptake index; TBG, thyroid hormone binding globulin; TBPA, thyroid hormone binding prealbumin; $T_{4}$, thyroxine; $T_{3}$, triiodothyronine.
J. Chopra and Mr. Darrel Mayes (Endocrine Sciences, Inc., Tarzana, Calif.).

All ${ }^{125}$ I-labeled compounds were at least $98 \%$ radiochemically pure based on cellulose thin-layer chromatography and radioscanning (Packard model 7230 radiochromatogram scanner, Packard Instrument Co., Inc., Downers Grove, Ill.). The solvent system used was chloroform 60 , tertiary butyl alcohol 376, $2 \mathrm{~N}$ ammonia 70 ; the following retardation factor $\left(R_{f}\right)$ values were obtained: thyroxine 0.15 , iodide 0.30 , triiodothyronine 0.41. Silica gel $\mathrm{H}$ (Analtech, Inc., Newark, Del.) was initially used as the stationary phase, but this material appeared to cause degradation of the thyronines.

The permeability of the hepatocyte cell membrane to the labeled compounds was measured by the tissue samplingsingle injection technique of Oldendorf (11) as adapted to liver $(12,13)$. A 200-300-g male Sprague-Dawley rat fed ad lib. was anesthetized with intraperitoneal pentobarbital (Diabutal, $45 \mathrm{mg} / \mathrm{kg}$, Diamond Laboratories, Des Moines, Iowa). The animal was placed in a supine position, laparotomized, and the hepatic artery was ligated. The portal vein was immediately cannulated with a 25 -gauge needle and $\sim 200 \mu$ l of buffered Ringer's solution $(\mathrm{pH}=7.4,5$ $\mathrm{mM}$ Hepes) was rapidly injected. This solution contained $2.5 \mu \mathrm{Ci} / \mathrm{ml}$ of $\left[{ }^{125} \mathrm{I}\right]$ thyronine, $25 \mu \mathrm{Ci} / \mathrm{ml}$ of ${ }^{3} \mathrm{H}$-water, a highly diffusible internal reference, and $0.1 \mathrm{~g} / 100 \mathrm{ml}$ bovine albumin. The albumin was added to prevent thyronine binding to the injection syringe. At $18 \mathrm{~s}$ after injection, a time sufficient for a single circulatory pass of the bolus through liver (12), the portal vein was transected and the right major lobe of liver was immediately removed. The liver tissue and the injection solution were prepared for double isotope ${ }^{3} \mathbf{H}$, ${ }^{125}$ I liquid scintillation counting as described previously (7, 10). The liver uptake index (LUI) was calculated as LUI(\%) $=\left({ }^{125} \mathrm{I} /{ }^{3} \mathrm{H}\right)$ disintegrations per minute (liver $) /\left({ }^{125} \mathrm{I} /{ }^{3} \mathrm{H}\right)$ disintegrations per minute (injection solution) $\times 100$. The LUI $=E_{T} / E_{R}$ where $E_{T}$ and $E_{R}$ are the percent extraction of the test and reference isotopes, respectively, at $18 \mathrm{~s}$ after rapid portal injection. Because $E_{R}$ is known under these experimental conditions $\left(E_{R}=0.65 \pm 0.04\right.$, mean $\pm S E, n=8$ rats, [7]), the LUI may be converted to $E_{T}$. The rate of liver blood flow under the present experimental conditions is $1.4 \mathrm{ml} / \mathrm{min}$ per $g$ (7); assuming a hematocrit of $40 \%$, the rate of plasma flow is $\sim 2.3 \mathrm{ml} / \mathrm{min}$ per $\mathrm{g}$. Given the rate of plasma flow $(\mathrm{F})$, the $\mathrm{E}_{\mathrm{T}}$ may be converted to unidirectional clearance $(\mathrm{Cl})$, i.e., $\mathrm{Cl}=\mathrm{E}_{\mathrm{T}} \mathrm{F}$. Since an $\mathrm{E}_{\mathrm{T}}$ of $13-15 \%$ reflects distribution only into the interstitial space of liver (see Results), the $\mathrm{Cl}$ for $\mathrm{T}_{3}$ or $\mathrm{T}_{4}$ must be corrected for extracellular distribution, so that a measure of unidirectional clearance into liver cells is obtained, e.g., $\mathrm{Cl}=\left(\mathrm{E}_{\mathrm{T}}-14 \%\right) \mathrm{F}$.

After determining the LUI and $\mathrm{E}_{\mathrm{T}}$ of $\mathrm{T}_{3}$ or $\mathrm{T}_{4}$ following injection of Ringer's solution, the effects of unlabeled $T_{3}$ and $T_{4}$ or the effects of plasma proteins, e.g., albumin or sera from various sources, may be investigated. Assuming plasma proteins inhibit $T_{3}$ or $T_{4}$ transport by binding the hormone and making the molecule unable to traverse the hepatocyte cell membrane, then the percent inhibition of hormone transport is a measure of the in vivo binding of the hormone by the plasma protein. The percentage of plasma hormone that is transported in vivo may be calculated (7), Percent transported $=\mathrm{LUI}_{\text {serum }}-\mathrm{LUI}_{\text {antiserum }} / \mathrm{LUI}_{\text {control }}-\mathrm{LUI}_{\text {antiserum }} \times 100$; where $L U I_{\text {serum }}=$ the LUI for $T_{3}$ or $T_{4}$ after injection of serum, LUI $_{\text {control }}=$ LUI after injection of Ringer's solution, and LUI $_{\text {antiserum }}=$ the LUI after injection of a $10 \%$ solution of rabbit antiserum specific for $T_{3}$ or $T_{4}$. The $L U I_{\text {antiserum was }}$ found to represent nonspecific distribution into the extracellular space (see Results).

The percentage of free (dialyzable) $\left[{ }^{125} \mathrm{I}\right] \mathrm{T}_{3}$ or $\left[{ }^{[25} \mathrm{I}\right] \mathrm{T}_{4}$ in 
the presence of either sera or a $2-\mathrm{g} / 100 \mathrm{ml}$ concentration of bovine albumin was determined as previously described (10).

Subsequent to the unidirectional influx of $T_{4}$ or $T_{3}$ into liver, the labeled hormone may either return to blood via efflux or be sequestered in liver cells by either a cell membrane active transport system or by binding to cytoplasmic protein. The sequestration of $T_{4}$ or $T_{3}$ was studied by measuring the rate of change in LUI during a 90 -s period after portal injection. Because $L U I=E_{T} / E_{R}$, the change in LUI with time is a function of $d E_{T} / d t$ and $d E_{R} / d t$. Water radioactivity is not sequestered by liver, so $d E_{R} / d t=-K_{\mathrm{R}} \mathrm{E}_{\mathrm{R}}$ or $E_{R}(t)=E_{R_{0}} e^{-K_{R} t}$, where $E_{R_{0}}=$ the extraction of the references at $\mathrm{t}=0$ and $K_{\mathrm{R}}=$ the efflux rate constant of the ${ }^{3} \mathrm{H}$ water reference. Previous studies have shown $K_{\mathrm{R}}=1.4 \mathrm{~min}^{-1}$ (7). The test compound may either be sequestered by liver or return to blood. If it is assumed that any $\left[{ }^{125} \mathrm{I}\right] \mathrm{T}_{3}$ or $\left[{ }^{125} \mathrm{I}\right] \mathrm{T}_{4}$ that enters liver cells is completely sequestered by liver during the 90 -s circulation period such that no efflux of $\mathrm{T}_{3}$ or $\mathrm{T}_{4}$ back to blood occurs, then $d E_{T} / d t=0$ and $\mathrm{E}_{\mathrm{T}}(\mathrm{t})=\mathrm{E}_{\mathrm{T}_{0}}$. Under these conditions $\mathrm{LUI}(\mathrm{t})=\mathrm{E}_{\mathrm{T}}(\mathrm{t}) / \mathrm{E}_{\mathrm{R}}(\mathrm{t})=\left(\mathrm{E}_{\mathrm{T}_{0}} / \mathrm{E}_{\mathrm{R}_{0}}\right) \mathrm{e}^{K_{\mathrm{R}}{ }^{t}}$ and $\ln \mathrm{LUI}(\mathrm{t})=\ln \mathrm{LUI}_{0}+K_{\mathrm{R}} \mathrm{t}(14)$. Therefore, a plot of $\ln$ LUI vs. time should be linear with a slope $K_{\mathrm{R}}=1.4 \mathrm{~min}^{-1}(7)$ and intercept $=$ LUI at zero time, if $T_{3}$ or $T_{4}$ were completely sequestered by liver.

Since sequestration of $T_{3}$ or $T_{4}$ radioactivity could be due to metabolism of the hormone to a nondiffusible labeled metabolite, the following experiment was done. A 5- $\mu \mathrm{Ci}$ bolus of [ $\left.{ }^{125} \mathrm{I}\right] \mathrm{T}_{3}$ was rapidly injected into the portal vein and $90 \mathrm{~s}$ later the right major lobe was freeze-clamped by aluminum blocks precooled in liquid nitrogen. The frozen tissue was pulverized with a mortar and pestle and was homogenized in a glass tissue grinder in cold 95\% methanol:ammonia (99:1). The homogenate was centrifuged at $4^{\circ} \mathrm{C}$ for $20 \mathrm{~min}$ at $3,000 \mathrm{~g}$ and the supernate was concentrated in a vacuum centrifuge evaporator (Savant Instruments Inc., Hicksville, N. Y.). The concentrated homogenate was spotted on a $250-\mu \mathrm{m}$ thin layer cellulose plate (Analtech Inc.) and developed in butanol 50: acetone 25:ammonia 18. The addition of $1 \mu \mathrm{Ci}$ of $\left[{ }^{[25} \mathrm{I}\right] \mathrm{T}_{3}$ to unlabeled liver homogenate served as a control and this was treated exactly as the experimental sample.

The relative lipid solubility of $T_{3}$ and $T_{4}$ were assessed by measuring the 1-octanol/Ringer's ( $\mathrm{pH} 7.4$ ) partition coefficient as described previously (3). The solution of $\left[{ }^{125} \mathrm{I}\right] \mathrm{T}_{3}$ or $\left[{ }^{125} \mathrm{I}\right] \mathrm{T}_{4}$ was made $25 \mu \mathrm{M}$ by addition of unlabeled $\mathrm{T}_{3}$ or $\mathrm{T}_{4}$, respectively, to minimize binding of the thyronines to glass. As noted previously, sequential 1-octanol/Ringer's solution partitions were run (3); the first partition removed any small, but highly polar impurity, e.g., $\left[{ }^{125} \mathrm{I}\right]$ iodide, which would tend to markedly lower the measured partition coefficient of the highly lipid soluble thyronines.

Statistical significance was assessed by Students' $t$ test.

\section{RESULTS}

The LUI of labeled $\mathrm{T}_{3}$ and $\mathrm{T}_{4}$ was $118 \pm 2 \%$ and $66 \pm 2 \%$ (Table I), respectively, after a bolus injection of hormone in Ringer's solution containing $0.1 \mathrm{~g} / 100 \mathrm{ml}$ bovine albumin. The corresponding extractions, $77 \pm 2 \%$ for $T_{3}$ and $43 \pm 2 \%$ for $T_{4}$, are given in Fig. 1. A small fraction of the $E_{T}$ for $T_{3}$ or $T_{4}$ represents distribution into the interstitial space of liver. A measure of extracellular distribution was obtained by injecting labeled $\mathrm{T}_{3}$ or $\mathrm{T}_{4}$ mixed with a solution of $10 \%$ rabbit antiserum that was specific for $T_{3}$ or $T_{4}$. Because of the slow debinding of $\mathrm{T}_{3}$ or $\mathrm{T}_{4}$ from an antibody (15), no transport of protein-bound hormone into liver occurs. Since only the trivial fraction of hormone that is free (dialyzable) will be available for transport after injection of antibody, the use of antisera provide a reliable measure of nonspecific distribution into the extracellular space. For example, the LUI of antibody-bound $\mathrm{T}_{3}$ or $\mathrm{T}_{4}$ (Table I) approximated the LUI for such extra-

TABLE I

Transport of $T_{3}$ and $T_{4}$ into Liver*

\begin{tabular}{|c|c|c|c|c|}
\hline \multirow{2}{*}{$\begin{array}{l}\text { Portal vein } \\
\text { injection } \\
\text { vehicle }\end{array}$} & \multicolumn{2}{|c|}{$\mathrm{T}_{3} \mathrm{t}, \S$} & \multicolumn{2}{|c|}{$T_{4} 1$} \\
\hline & LUI & Transported & LUI & Transported \\
\hline & $\%$ & $\%$ & $\%$ & $\%$ \\
\hline Ringer's solution & $118 \pm 29$ & 100 & $66 \pm 29$ & 100 \\
\hline Rat & $100 \pm 59$ & 81 & $31 \pm 29$ & 18 \\
\hline Normal human & $91 \pm 69$ & 72 & $28 \pm 29$ & 11 \\
\hline Oral contraceptives & $83 \pm 59$ & 64 & $25 \pm 2$ & 4 \\
\hline Pregnancy & $81 \pm 49$ & 62 & $25 \pm 2$ & 4 \\
\hline Cord blood & $77 \pm 6$ & 58 & $25 \pm 1$ & 4 \\
\hline Antiserum (10\%) & $20 \pm 3$ & 0 & $22 \pm 1$ & 0 \\
\hline
\end{tabular}

* Data are mean \pm SEM ( $n=6-8$ rats per group; serum was obtained from 6-8 different volunteers or patients in each group).

\$ LUI = liver uptake index; \% transported = the fraction of total hormone available for transport into liver cells (see text for calculations).

\$ Comparison of the LUI for $T_{3}$ after injection of rat serum to the LUI after injection of human serum resulted in the following $P$ values; normal human $(P<0.15)$, oral contraceptives $(P<0.025)$, pregnancy $(P<0.01)$, cord $(P<0.01)$. १ Significantly different from antiserum $(P<0.05)$. 


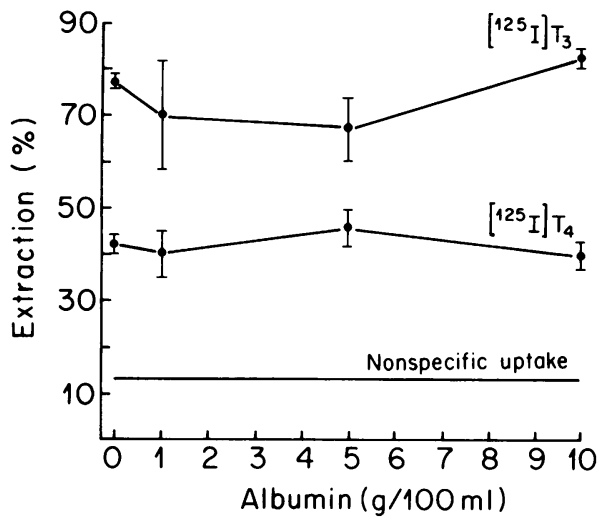

Figure 1 The extraction of unidirectional influx of $T_{4}$ and $\mathrm{T}_{3}$ into liver vs. the concentration of bovine albumin in the portal vein injection solution. The nonspecific uptake reflects the distribution into the interstitial space and is equal to $T_{4}$ or $\mathrm{T}_{3}$ clearance after injection of antiserum (Table I).

cellular space markers as $\left.{ }^{125} \mathrm{I}\right]$ iodide, $21 \pm 1 \%$ (mean \pm SEM, $n=3$ rats), or $\left[{ }^{14} \mathrm{C}\right]$ sucrose, $20 \pm 5 \%$ (7). ${ }^{2}$ Since the average $\mathrm{E}_{\mathrm{T}}$ for extracellular distribution is $14 \%$ (Fig. 1), the corrected $\mathrm{E}_{\mathrm{T}}$ representing intracellular distribution of $\mathrm{T}_{3}$ and $\mathrm{T}_{4}$ is 63 and $29 \%$, respectively, in the absence of plasma protein binding. After injection of labeled hormone mixed in rat serum, the $E_{T}$ (corrected for extracellular distribution) for $T_{3}$ and $\mathrm{T}_{4}$ is 51 and $6 \%$, respectively (Fig. 2). Therefore, the unidirectional clearance for $\mathrm{T}_{3}$ or $\mathrm{T}_{4}$ by liver in the rat is 1.2 and $0.14 \mathrm{ml} \mathrm{min}^{-1} \mathrm{~g}^{-1}$, respectively, given $\mathrm{Cl}=\mathrm{E}_{\mathrm{T}} \mathrm{F}$ and $\mathrm{F}=2.3 \mathrm{ml} \mathrm{min} \mathrm{m}^{-1} \mathrm{~g}^{-1}$ (Methods). The latter estimate for unidirectional $\mathrm{T}_{4}$ clearance by rat liver approximates previous measurements by Hasen et al. (16).

Albumin is known to actively bind both $\mathrm{T}_{3}$ and $\mathrm{T}_{4}$. For example, a $2-\mathrm{g} / 100 \mathrm{ml}$ concentration of bovine albumin bound $98.4 \pm 0.2$ and $99.3 \pm 0.2 \%$ of a tracer concentration $(10 \mathrm{nM})$ of $\left[{ }^{125} \mathrm{I}\right] \mathrm{T}_{3}$ and $\mathrm{T}_{4}$, respectively, in vitro as determined by equilibrium dialysis at $37^{\circ} \mathrm{C}$. Conversely, when increasing concentrations of albumin were added to the injection solution, there was no significant change in the extraction of $T_{3}$ or $T_{4}$ by liver (Fig. 1). These results indicate $T_{3}$ or $T_{4}$ bound by albumin is freely available for transport into liver cells.

The availability for transport of hormone bound to TBPA was investigated by making the final injection solution $67 \%$ rat serum. The only thyroid hormone binding proteins in rat serum are albumin and TBPA; the latter protein actively binds $T_{4}$, but binds $T_{3}$ to a much lesser extent (1). As shown in Fig. 2, rat serum had a marked inhibitory effect on $\mathrm{T}_{4}$ transport and a

\footnotetext{
${ }^{2}$ In addition, the LUI for antisera-bound $T_{3}$ or $T_{4}$ approximates the value for a plasma protein, e.g., the LUI of ${ }^{125} \mathrm{I}$ fetuin is $22 \pm 3 \%$. Pardridge, W. M., and A. J. Van Herle, unpublished results.
}

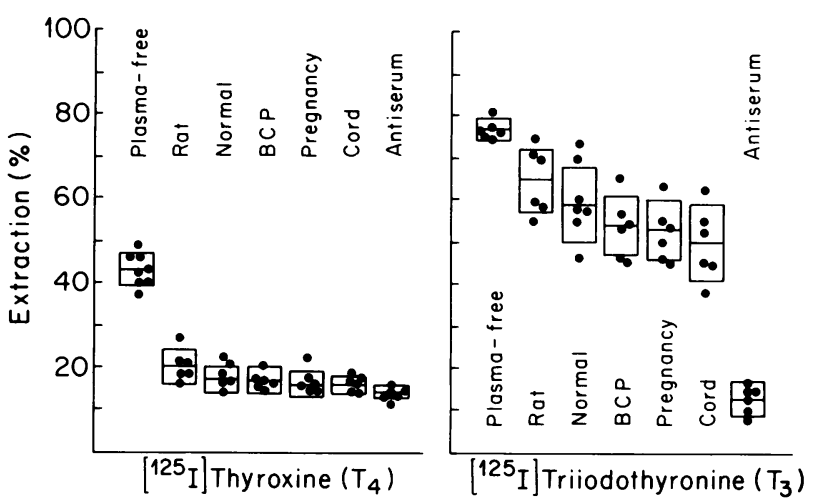

FIgURE 2 The extraction of $\mathrm{T}_{4}$ or $\mathrm{T}_{3}$ by rat liver vs. the type of serum added to the injection solution. Plasma-free solutions contained $0.1 \mathrm{~g} / 100 \mathrm{ml}$ bovine albumin; $\mathrm{T}_{4}$ or $\mathrm{T}_{3}$ antiserum solutions were diluted to $10 \%$; all other samples were injected as $67 \%$ serum solutions. Each point represents a different patient, volunteer, or animal. The boxes represent the mean $\pm S D$. Normal human and cord samples were obtained from both males and females; BCP, birth control pills.

much lesser effect on $\mathrm{T}_{3}$ flux into liver, i.e., $18 \%$ of total $\mathrm{T}_{4}$ was available for transport vs. $81 \%$ for $\mathrm{T}_{3}$ (Table I). In addition to albumin and TBPA, human serum contains TBG (1), and this latter protein is elevated in either pregnancy or oral estrogen use (1). The effects of $67 \%$ serum solution from four different human sources (normal, oral contraceptive, pregnancy, and cord blood) on $\mathrm{T}_{3}$ or $\mathrm{T}_{4}$ transport into liver are shown in Fig. 2. Human serum had a marked inhibitory effect on $\mathrm{T}_{4}$ transport (Fig. 2) and only the LUI of $\mathrm{T}_{4}$ bound to normal serum was statistically significantly different from the LUI of antiserum-bound $\mathrm{T}_{4}$. Conversely, $\mathrm{T}_{3}$ was readily transported into liver after injection of $T_{3}$ bound to human serum (Fig. 2). The amount of total $\mathrm{T}_{3}$ available for transport into liver ranged from 58 to $72 \%$ for the human serum samples (Table I). However, the fraction of plasma $T_{3}$ cleared by liver after injection of serum containing elevated TBG (oral contraceptives or pregnancy) was not statistically different from normal human serum (Table I). Yet in the case of the sera samples obtained from pregnant volunteers, the free (dialyzable) fraction in vitro was decreased $50 \%$ compared with normal human serum (Table II). Cord serum, which contains high normal levels of TBG (17) and which binds high normal fractions of $\mathrm{T}_{3}$ in vitro (Table II) inhibited [ $\left.{ }^{125} \mathrm{I}\right] \mathrm{T}_{3}$ transport to the greatest degree (Table I); these results suggest the $\mathrm{T}_{3}$ debinding rate from cord TBG may be somewhat slower than normal.

The saturability of labeled $\mathrm{T}_{3}$ or $\mathrm{T}_{4}$ transport was assessed by making the final injection solution $50 \mu \mathrm{M}$ in either $T_{3}$ or $T_{4}$. Under these conditions, the LUI for $T_{3}, 117 \pm 9 \%$, or for $T_{4}, 60 \pm 1 \%$, was not significantly different from the control (Table I).

In order for the LUI to accurately reflect the extrac- 
TABLE II

Free (Dialyzable) $T_{3}$ In Vitro*

\begin{tabular}{lc}
\hline \multicolumn{1}{c}{ Serum source } & Dialyzable $\left[{ }^{125} \mathrm{I}\right] \mathrm{T}_{3}$ \\
\hline & $\%$ \\
Rat & $0.93 \pm 0.08$ \\
Normal human & $0.30 \pm 0.03$ \\
Cord blood & $0.25 \pm 0.02$ \\
Pregnancy & $0.15 \pm 0.01$ \\
$\mathrm{~T}_{3}$ antiserum $(10 \%)$ & $0.053 \pm 0.003$ \\
\hline
\end{tabular}

* Data are mean $\pm \operatorname{SEM}(n=6$ per group). Dialysis was performed on serum diluted to $10 \%$ and on antiserum diluted to $1 \%$, and the measured percentages were divided by 10 to arrive at the reported values.

tion or unidirectional influx into liver, it must be shown that the test compound cleared by liver cells does not efflux back to blood during the 18-s circulation period (13). Hormone efflux was studied by prolonging the circulation time after injection up to $90 \mathrm{~s}$ (Fig. 3). The rate of increase in the LUI for $\mathrm{T}_{3}$ or $\mathrm{T}_{4}, 1.4 \mathrm{~min}^{-1}$, is exactly equal to the rate of washout of the ${ }^{3} \mathrm{H}$-water reference (7). As indicated in Methods, these observations indicate that $\mathrm{T}_{3}$ or $\mathrm{T}_{4}$ radioactivity is completely sequestered by liver for at least $90 \mathrm{~s}$ after injection. Therefore, no efflux of $\mathrm{T}_{3}$ or $\mathrm{T}_{4}$ during the 18-s circu-

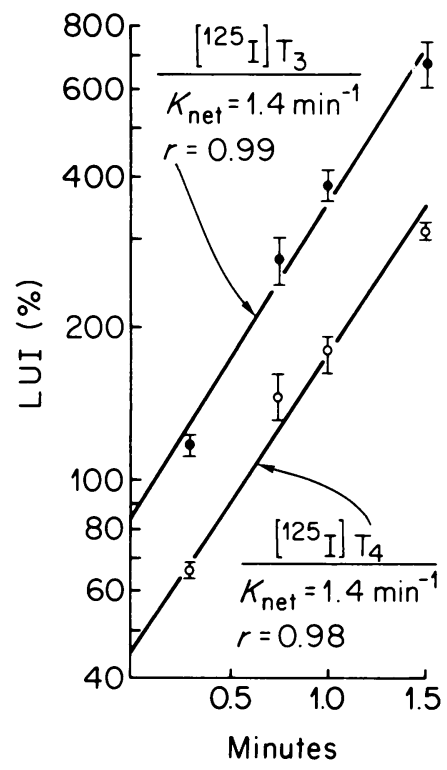

Figure 3 The LUI for $\mathrm{T}_{3}$ or $\mathrm{T}_{4}$ is plotted vs. circulation time after rapid portal injection. The $K_{\text {net }}=$ the slope determined by linear regression analysis. The rate of increase in LUI is equal to the rate of washout of the ${ }^{3} \mathrm{H}$-water reference, $K=1.4 \mathrm{~min}^{-1}(7)$. The observation that the change in LUI with time is only a function of ${ }^{3} \mathrm{H}$-water washout indicates both $T_{3}$ and $T_{4}$, after unidirectional clearance by liver cells, are essentially completely sequestered by liver for at least $90 \mathrm{~s}$ after injection. lation period occurs, and the LUI can be considered a reliable index of $\mathrm{E}_{\mathrm{T}}$.

The process mediating sequestration of $T_{3}$ radioactivity was not saturated by making the injection solution $50 \mu \mathrm{M} \mathrm{T}$; e.g., the 90-s LUI, $523 \pm 49$ (mean \pm SEM, $n=3$ rats), was not significantly different from the control (Fig. 3). Conversion of $T_{3}$ to a polar metabolite could explain the sequestration of the hormone; therefore, the liver was freeze-clamped $90 \mathrm{~s}$ after injection of labeled $\mathrm{T}_{3}$ (Methods). Thin-layer chromatography and radioscanning of the liver homogenate revealed only one peak which comigrated exactly with the $\left.{ }^{[25} \mathrm{I}\right] \mathrm{T}_{3}$ standard; these results suggest $\mathrm{T}_{3}$ is not significantly metabolized during the 90 -s period after injection.

The 1-octanol/Ringer's ( $\mathrm{pH}$ 7.4) partition coefficients for $\left[{ }^{125} \mathrm{I}\right] \mathrm{T}_{3}$ and $\left[{ }^{125} \mathrm{I}\right] \mathrm{T}_{4}$ were $180 \pm 10$ and $91 \pm 14$ (mean $\pm \mathrm{SEM}, n=3)$, respectively.

\section{DISCUSSION}

These studies bear on two aspects of hepatocyte plasma membrane transport of $\mathrm{T}_{4}$ and $\mathrm{T}_{3} ;(a)$ the mechanism by which $\mathrm{T}_{4}$ or $\mathrm{T}_{3}$ traverses the hepatocyte cell membrane, and $(b)$ the role of the thyroid hormone binding plasma proteins in limiting transmembrane transport.

In general, compounds such as $T_{4}$ or $T_{3}$ may traverse the liver cell membrane by one of two mechanisms: (a) lipid-mediation (free diffusion), which does not involve ligand binding at the cell membrane, or $(b)$ carrier-mediation (facilitated diffusion, active transport), which involves $T_{4}$ or $T_{3}$ binding to a cell membrane transport system. The evidence presented here and by others (18) suggest $T_{3}$ and $T_{4}$ enter liver cells via lipid mediation. Hillier (18) has previously shown that $T_{4}$ or $T_{3}$ transport into the perfused rat liver is nonsaturable up to a thyronine concentration of $1 \mu \mathrm{M}$. Similarly, $\left[{ }^{125} \mathrm{I}\right] \mathrm{T}_{3}$ or $\left[{ }^{125} \mathrm{I}\right] \mathrm{T}_{4}$ transport in vivo is not affected by a $50-\mu \mathrm{M}$ concentration of hormone (Results). Further evidence in favor of lipid mediation is the high lipid solutility of $\mathrm{T}_{3}$ or $\mathrm{T}_{4}$, e.g., the octanol/ Ringer's partition coefficients for $T_{3}$ and $T_{4}$ is 180 and 90, respectively (Results).

The high partition coefficients for $T_{4}$ and $T_{3}$ measured here are in contrast to the heptane/saline ratios reported for $T_{4}, 0.0004$, and $T_{3}, 0.3$ (19). However, Dietschy (20) has emphasized the importance of using polar organic solvents, not nonpolar solvents such as heptane, to mimic the lipid solubility of biological membranes. For example, if a highly polar lipid such as lecithin is used, the lipid partition coefficient for $T_{4}(12,000)$ or $T_{3}(22,000)$ is very high $(21)$.

Although the high lipid solubility of $T_{4}$ and $T_{3}$ and the nonsaturability of thyronine transport into liver is evidence in favor of lipid-mediation, other studies re- 
port data in favor of carrier-mediation $(22,23)$. The transport of $\mathrm{T}_{3}$ into isolated liver cells at $21-23^{\circ} \mathrm{C}$ has been shown to be saturable $(22,23)$. A similar discrepancy has been observed for liver cell membrane transport of the steroid hormones, wherein steroid transport in vivo is nonsaturable (7), but hormone transport in vitro is saturable (24). However, it is likely that extracellular steroid or thyroid hormone equilibrates instantaneously in vitro where the volume of extracellular fluid is log orders greater than the intracellular space; under these conditions, the major factor determining hormone uptake might be intracellular binding systems. Indeed, the cell/medium ratio of labeled $\mathrm{T}_{3}$ in isolated liver cells is $20-30$ by only $20 \mathrm{~s}$ of incubation (23); these data suggest that the process of transmembrane movement of $\mathrm{T}_{3}$ reaches equilibrium nearly instantaneously in vitro, and that the net uptake of $\mathrm{T}_{3}$ by the liver cell is determined primarily by an intracellular sequestration system. The data in Fig. 3 indicate that once radiolabeled $T_{3}$ or $T_{4}$ enter liver cells, these molecules are immediately and completely sequestered by intracellular binding systems. In regard to the present in vivo approach, it is unlikely that $\mathrm{T}_{3}$ or $\mathrm{T}_{4}$ equilibrate instantaneously across the hepatocyte cell membrane because the extraction of $\mathrm{T}_{3}\left(\mathrm{E}_{\mathrm{T}}\right.$ $=77 \pm 2 \%)$ or $\mathrm{T}_{4}\left(\mathrm{E}_{\mathrm{T}}=43 \pm 2 \%\right)$ is not in excess of $95 \%$, which would be expected if instantaneous equilibration occurred. Therefore, results obtained with a portal vein injection method can be considered to accurately reflect the kinetics of transmembrane transport of $T_{3}$ or $\mathrm{T}_{4}$ and to be independent of intracellular binding systems.

The need for an experimental approach that accurately measures unidirectional influx of $T_{3}$ or $T_{4}$ through the liver cell membrane is also of importance in assessing the effect of the plasma proteins on the transport of circulating $\mathrm{T}_{4}$ or $\mathrm{T}_{3}$ into liver cells. As shown by Oppenheimer and associates (25), the net uptake of thyroid hormones is strongly influenced by intracellular binding systems; therefore, if net clearance of thyroid hormone is measured, the separation of plasma protein effects from cytoplasmic protein effects may be difficult.

In addition to permitting the measurement of unidirectional influx, the portal vein injection technique used in the present studies has the novel advantage of allowing the study of human sera in an in vivo rat liver paradigm (7). Because the rate of portal injection exceeds the rate of portal blood flow, the injection solution enters the liver circulation as a bolus, which makes a single pass of liver without appreciable mixing with circulating rat plasma. Therefore, the concentration of plasma proteins added to the injection solution approxi. mates the composition of the microvasculature at the time of $\left[{ }^{125} \mathrm{I}\right] \mathrm{T}_{3}$ or $\left[{ }^{125} \mathrm{I}\right] \mathrm{T}_{4}$ transport. The maintenance of bolus flow has been documented in numerous studies of brain capillary transport using a carotid injection technique $(3,10,26)$. A similar maintenance of bolus flow occurs in liver transport studies, as shown by the marked difference in $\mathrm{T}_{4}$ transport, depending on whether Ringer's solution $\left(\mathrm{E}_{\mathrm{T}}=43 \pm 2 \%\right)$ or rat serum $\left(E_{T}=20 \pm 2 \%\right.$ ) is injected (Fig. 2). If appreciable mixing of the injection solution with rat plasma occurred during bolus transit through the liver, then the relatively high $E_{T}$ for $T_{4}$ after injection of Ringer's solution would not be observed. ${ }^{3}$

Rat plasma contains two $\mathrm{T}_{4}$ binding proteins, albumin and TBPA $(27,28)$. Although albumin binds considerable quantities of $\mathrm{T}_{4}$, albumin-bound $\mathrm{T}_{4}$ is readily dissociated and transported into liver (Fig. 1). Therefore, the $82 \%$ inhibition (Table I) of intracellular distribution of $T_{4}$ by rat serum may be attributed to TBPA. Based on the data of Sutherland and associates (27), it may be calculated that $86 \%$ of rat plasma $\mathrm{T}_{4}$ is TBPA-bound and $14 \%$ is albumin bound. ${ }^{4}$ Therefore, the percent inhibition of $T_{4}$ transport by rat plasma correlates with the percent distribution of $T_{4}$ to TBPA; and the albumin-bound moiety approximates the fraction of $T_{4}$ transported in vivo (Fig. 1). Human serum results in an even greater inhibition of $\mathrm{T}_{4}$ transport (Fig. 2); the presence of TBG results in a lowering to $5-10 \%$ of the percent distribution of $\mathrm{T}_{4}$ to albumin (29). Since the percent of $T_{4}$ bound to albumin in human serum $(5-10 \%)$ approximates the experimental variability $(5-10 \%)$ of the technique (Table I), a LUI for $T_{4}$ that is statistically different from the antiserum background is obtained only for normal human serum (Table I). In addition to the data in Figs. 1 and 2, there is experimental evidence in man, consistent with the proposal that albumin-bound $\mathrm{T}_{4}$ is readily available for transport into liver. Unidirectional extraction of $\mathrm{T}_{4}$ clearance by human liver, as determined by a venous sampling-single injection technique, is $7 \%$ (30). The value is 200 times the free (dialyzable) $\mathrm{T}_{4}$ fraction, $\sim 0.03 \%$ (1), and approximates the albuminbound $T_{4}$ fraction in human serum (29). Because the hepatic capillary transit times are likely to be of similar magnitude in the rat and in man, it is probable that the

\footnotetext{
${ }^{3}$ It might be argued that the real $E_{T}$ for $T_{4}$ is much higher than $43 \pm 2 \%$ and mixing of the bolus with circulating rat TBPA did occur and resulted in a lowering of $E_{T}$ to $43 \%$. However, if this were the case, the injection of $50 \mu \mathrm{M}$ unlabeled $\mathrm{T}_{4}$ (Results) would have saturated all TBPA binding sites and caused an elevation in $\mathrm{E}_{\mathrm{T}}$ for $\mathrm{T}_{4}$. Since no increase was observed, it is concluded that no significant mixing of the bolus with rat plasma occurred.

${ }^{4}$ The percent distribution of $\mathrm{T}_{4}$ or $\mathrm{T}_{3}$ may be approximated by $(\mathrm{BIa}) / \Sigma \mathrm{BI}$, where $\mathrm{BIa}$ is the binding index (binder concentration $\div$ dissociation constant) of the protein in question and $\Sigma B I$ is the sum of binding indices of all thyronine binding plasma proteins (1).
} 
$7 \%$ unidirectional extraction of $\mathrm{T}_{4}$ in human liver represents distribution into liver cells of $T_{4}$ bound to albumin.

Since both the free (dialyzable) and albumin-bound fractions are inversely related to the existing TBG level, unidirectional $\mathrm{T}_{4}$ clearance by liver is regulated by changes in TBG. In contrast to $T_{4}$, the data in Fig. 2 and Table $I$ indicate that the transport of $\mathrm{T}_{3}$ bound to TBG into liver cells is extensive. About $70 \%$ of total $\mathrm{T}_{3}$ is bound to TBG and about $30 \%$ is bound to albumin (31). Because the $T_{3}$ that is albumin-bound is freely cleared by liver, the observation that $60-70 \%$ of total $\mathrm{T}_{3}$ is available for transport (Table $I$ ) indicates that half of the $T_{3}$ bound to TBG is available for transport into liver. Moreover, the observation that conditions in which TBG is elevated, e.g., pregnancy or oral contraceptive use (1), are characterized by only a negligible inhibition of $\mathrm{T}_{3}$ transport (Fig. 2) is consistent with the proposal that TBG-bound $T_{3}$ is readily available for transport into liver. The conclusion that TBG exerts relatively little influence over the unidirectional hepatic clearance of $\mathrm{T}_{3}$ has been suggested previously by Zaninovich et al. (32). Although the experimental approach used by these workers (32) has since been criticized as an unreliable measurement of unidirectional clearance (33), it is significant that the studies reported herein lead to the same conclusions originally suggested by Zaninovich and co-workers (32).

The fractions of plasma $T_{4}$ or $T_{3}$ that are available for transport into liver are different from the fraction of hormone available for transport into brain. Only a small fraction $(\sim 10 \%)$ of albumin-bound $\mathrm{T}_{3}$, and probably no TBG-bound $T_{3}$, is transported into the brain (10). The basis for the different rate of transport of proteinbound thyroid hormone into brain and liver would appear to be twofold. Firstly, the permeability of the liver cell membrane to $T_{3}$ and $T_{4}$ is much greater in liver (Table I, [10]). Secondly, the capillary transit time is considerably longer in hepatic sinusoids relative to brain capillaries $(3,6)$. As mentioned in the introduction, the capillary transit time, membrane permeability, and ligand unidirectional debinding rates, appear to be the major factors that determine the extent to which protein-bound hormones are transported into tissues $(3,7,10,34-36)$.

Finally, the relationship between the unidirectional clearance estimates for $T_{4}$ and $T_{3}$ reported in the present studies and the net or bidirectional hepatic clearance of hormone should be discussed. As emphasized by Oppenheimer and associates (25), the net retention of thyroid hormone by liver is a function of the tissue binding index ${ }^{3}$ relative to the plasma binding index. Assuming no changes occur in tissue binding of thyroid hormone, then alterations in plasma binding parameters should reliably predict the net transport of the hormone into the tissue. However, what is less certain is whether in vitro measurements, e.g., Table II, accurately estimate the in vivo binding index of thyroid binding plasma proteins. Despite the extensive unidirectional transport of protein-bound thyroid hormones into tissues, it might be argued that the net flux of hormone is inversely related to the total binding index of the plasma, which is reliably estimated by the in vitro free (dialyzable) fraction (25). However, it is our view $(3,7,10,34-36)$ that, under many circumstances, the transport of protein-bound hormones into tissues in vivo cannot be accurately predicted by the in vitro binding index. The in vivo measurement of plasma protein binding in the model we have used, i.e., Table I, may provide a more accurate index of what is actually transported than does an in vitro assay. However, if only albumin-bound hormone is available for transport into the tissue, e.g., $\mathrm{T}_{4}$ or $\mathrm{T}_{3}$ influx into brain (10) or $T_{4}$ influx into liver (Fig. 1), then the in vitro free hormone fraction should reliably predict the amount of plasma hormone available for transport. This is because both the free (dialyzable) and albuminbound fractions will, under most circumstances, be inversely related to the existing TBG or TBPA levels. Conversely, both albumin-bound and TBG-bound $\mathrm{T}_{3}$ are readily available for transport into liver (Fig. 1). Under these conditions, increases in TBG concentrations, e.g., pregnancy or estrogen treatment, would be expected to substantially reduce the free (dialyzable) fraction in vitro (Table II), yet have relatively little influence on the plasma binding of $T_{3}$ in liver sinusoids in vivo (Table I, Fig. 2). Therefore, it is probable that in vitro measurements of free $T_{3}$ do not reliably predict $T_{3}$ clearance by liver in vivo.

\section{ACKNOWLEDGMENTS}

The authors are indebted to Drs. Andre Van Herle, Inder Chopra, and Joseph Distefano, III, for many valuable discussions. Antisera were graciously provided by Dr. Chopra and by Darrel Mayes of Endocrine Sciences, Inc., Tarzana, Calif.

This research was funded by the National Science Foundation (BNS 78-05500), by a Basil O'Connor Starter Research Grant from the National Foundation March of Dimes, and by National Institutes of Health grant AM-25744. Charlotte Limberg provided excellent secretarial assistance.

\section{REFERENCES}

1. Robbins, J., J. E. Rall, and P. Gorden. 1974. The thyroid and iodine metabolism. In Duncan's Diseases of Metabolism. P. K. Bondy and L. E. Rosenberg, editors. W. B. Saunders Company, Philadelphia. 1009-1104.

2. Woeber, K. A., E. Hecker, and S. H. Ingbar. 1970. The effects of an acute load of thyroxine on the transport and peripheral metabolism of triiodothyronine in man. $J$. Clin. Invest. 49: 650-654. 
3. Pardridge, W. M., and L. J. Mietus. 1979. Transport of steroid hormones through the rat blood-brain barrier. Primary role of albumin-bound hormone. J. Clin. Invest. 64: 145-154.

4. Heyns, W., and P. De Moor. 1971. Kinetics of dissociation of $17 \beta$-hydroxysteroids from the steroid binding $\beta$-globulin of human plasma. J. Clin. Endocrinol. 32: 147-154.

5. Dixon, P. F. 1968. The kinetics of the exchange between transcortin-bound and unbound cortisol in plasma. $J$. Endocrinol. 40: 457-465.

6. Goresky, C. A., and C. P. Rose. 1977. Blood-tissue exchange in liver and heart: the influence of heterogeneity of capillary transit times. Fed. Proc. 36: 2629-2643.

7. Pardridge, W. M., and L. J. Mietus. 1979. Transport of protein-bound steroid hormones in liver in vivo. Am. J. Physiol. 237: E367-E372.

8. Hillier, A. P. 1975. The rate of triiodothyronine dissociation from binding sites in human plasma. Acta Endocrinol. 80: 49-57.

9. Hillier, A. P. 1971. Human thyroxine-binding globulin and thyroxine-binding pre-albumin: dissociation rates. J. Physiol. (Lond.) 217: 625-634.

10. Pardridge, W. M. 1979. Carrier-mediated transport of thyroid hormones through the rat blood-brain barrier: primary role of albumin-bound hormone. Endocrinology. 105: 605-612.

11. Oldendorf, W. H. 1970. Measurement of brain uptake of radio-labeled substances using a tritiated water internal standard. Brain Res. 24: 372-376.

12. Pardridge, W. M., and L. S. Jefferson. 1975. Liver uptake of amino acids and carbohydrates during a single circulatory passage. Am. J. Physiol. 228: 1155-1161.

13. Pardridge, W. M. 1977. Unidirectional influx of glutamine and other neutral amino acids into liver of fed and fasted rat in vivo. Am. J. Physiol. 232: E492-E496.

14. Pardridge, W. M., T. L. Moeller, L. J. Mietus, and W. H. Oldendorf. 1980. Blood-brain barrier transport and brain sequestration of the steroid hormones. Am. J. Physiol. 239: E96-E102.

15. Premachandra, B. N., and I. I. Ibrahim. 1975. Thyroxine antibody vs. serum protein binding of $\mathrm{T}_{4}$ in the cold; differential charcoal adsorption of $\mathrm{T}_{4}$ from immuno and conventional $\mathrm{T}_{4}$ binding sites. In Thyroid Hormone Metabolism. W. A. Harland and J. S. Orr, editors. Academic Press, Inc., New York. 281-297.

16. Hasen, J., G. Bernstein, E. Volpert, and J. H. Oppenheimer. 1968. Analysis of the rapid interchange of thyroxine between plasma and liver and plasma and kidney in the intact rat. Endocrinology. 82: 37-46.

17. Burman, K. D., J. Read, R. C. Diamond, D. Strum, F. D. Wright, W. Patow, J. M. Earll, and L. Wartofsky. 1976. Measurements of 3,3',5'-triiodothyronine (Reverse $\mathrm{T}_{3}$ ), 3,3'-L-diiodothyronine, $\mathrm{T}_{3}$ and $\mathrm{T}_{4}$ in human amniotic fluid and in cord and maternal serum. J. Clin. Endocrinol. Metab. 43: 1351-1359.

18. Hillier, A. P. 1969. The release of thyroxine from serum protein in the vessels of the liver. J. Physiol. (Lond.) 203: 419-434.

19. Hagen, G. A., and L. A. Solberg, Jr. 1974. Brain and cerebrospinal fluid permeability to intravenous thyroid hormones. Endocrinology. 95: 1398-1410.

20. Dietschy, J. M. 1978. General principles governing movement of lipids across biological membranes. In Disturbances in Lipid and Lipoprotein Metabolism. J. M.
Dietschy, A. M. Botto, Jr., and J. A. Ontko, editors. American Physiological Society, Bethesda, Md. 1-28.

21. Hillier, A. P. 1970. The binding of thyroid hormones to phospholipid membranes. J. Physiol. (Lond.) 211: 585597.

22. Krenning, E. P., R. Docter, H. F. Bernard, T. J. Visser, and G. Hennemann. 1978. Active transport of triiodothyronine $\left(\mathrm{T}_{3}\right)$ into isolated rat liver cells. FEBS (Fed. Eur. Biochem. Soc.) Lett. 91: 113-116.

23. Eckel, J., G. S. Rao, M. L. Rao, and H. Breuer. 1979. Uptake of L-Tri-iodothyronine by isolated rat liver cells. A progress partially inhibited by metabolic inhibitors; attempts to distinguish between uptake and binding to intracellular proteins. Biochem. J. 182: 473-491.

24. Rao, M. L., G. S. Rao, and H. Breuer. 1977. Uptake of estrone, estradiol-17 $\beta$ and testosterone by isolated rat liver cells. Biochem. Biophys. Res. Commun. 77: 566573.

25. Oppenheimer, J. H., G. Bernstein, and J. Hasen. 1967. Estimation of rapidly exchangeable cellular thyroxine from the plasma disappearance curves of simultaneously administered thyroxine- ${ }^{131} \mathrm{I}$ and albumin-125I. J. Clin. Invest. 46: 762-777.

26. Oldendorf, W. H. 1971. Brain uptake of radiolabeled amino acids, amines, and hexoses after arterial injection. Am. J. Physiol. 221: 1629-1639.

27. Sutherland, R. L., and M. R. Brandon. 1976. The thyroxine-binding properties of rat and rabbit serum proteins. Endocrinology. 98: 91-98.

28. Peterson, P. A., L. Rask, L. Ostberg, L. Andersson, F. Kamwendo, and H. Pertoft. 1973. Studies on the transport and cellular distribution of vitamin $A$ in normal and vitamin A-deficient rats with special reference to the vitamin A-binding plasma protein. J. Biol. Chem. 248: 4009-4022.

29. Hamada, S., T. Nakagawa, T. Mori, and K. Torizuka. 1970. Re-evaluation of thyroxine binding and free thyroxine in human serum by paper electrophoresis and equilibrium dialysis, and a new free thyroxine index. J. Clin. Endocrinol. 31: 166-179.

30. Dowling, J. T., W. G. Appleton, and B. U. Musa. 1968. Direct measurement of hepatic thyroxine flux in normal man. J. Clin. Endocrinol. 28: 1503-1507.

31. Hagen, G. A., and W. J. Elliott. 1973. Transport of thyroid hormones in serum and cerebrospinal fluid. J. Clin. Endocrinol. Metab. 37: 415-422.

32. Zaninovich, A. A., H. Farach, C. Ezrin, and R. Volpe. 1966. Lack of significant binding of L-triiodothyronine by thyroxine-binding globulin in vivo as demonstrated by acute disappearance of ${ }^{131}$ I-labeled triiodothyronine. J. Clin. Invest. 45: 1290-1301.

33. Musa, B. U., R. S. Kumar, and J. T. Dowling. 1969. Role of thyroxine-binding globulin in the early distribution of thyroxine and triiodothyronine. J. Clin. Endocrinol. 29: 667-674.

34. Pardridge, W. M. 1979. Tryptophan transport through the blood-brain barrier: in vivo measurement of free and albumin-bound amino acid. Life Sci. 25: 1519-1528.

35. Pardridge, W. M. and L. J. Mietus. 1980. Effects of progesterone binding globulin vs. a progesterone antiserum on steroid hormone transport through the bloodbrain barrier. Endocrinology. 106: 1137-1141.

36. Pardridge, W. M., L. J. Mietus, A. M. Frumar, B. J. Davidson, and H. L. Judd. 1980. Effects of human serum on the transport of testosterone and estradiol into rat brain. Am. J. Physiol. 239: E103-E108. 